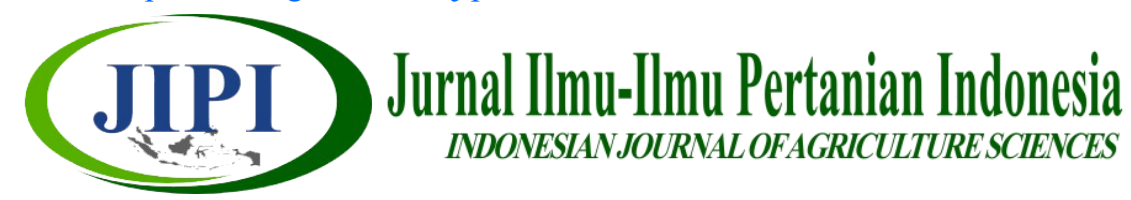

\title{
PERTUMBUHAN DAN HASIL EMPAT VARIETAS TANAMAN KACANG HIJAU (Vigna radiata L.) PADA PEMBERIAN DOSIS PUPUK KANDANG AYAM DI ULTISOL
}

\author{
Robi Candra ${ }^{1}$, Sumardi ${ }^{1}$, Hermansyah ${ }^{1^{*}}$ \\ ${ }^{1}$ Program Studi Agroekoteknologi, Fakultas Pertanian Universitas Bengkulu \\ * Corresponding Author: hermansyah@unib.ac.id
}

\begin{abstract}
[GROWTH AND YIELD OF FOUR VARIETIES OF MUNG BEAN (Vigna radiata L.) PLANT ON DOSING OF CHICKEN MANURE FERTILIZER IN ULTISOL]. Ultisols generally have less favorable physical, chemical, and biological properties. Chicken manure is believed to be able to improve soil structure, increase water holding capacity, increase soil $\mathrm{pH}$, increase cation exchange capacity, increase soil biological activity, and facilitate root penetration. This study aims to determine the optimum dose of chicken manure in increasing the growth and yield of four mung bean varieties in Ultisol. This research was conducted using a split-plot design. The doses of chicken manure ( 0 tons/ha, 10 tons/ha, 20 tons/ha, and 30 tons/ha) were placed in the main plots and mung bean varieties (Vima-1, Vima-2, Kutilang, and Murai) as children. plots with experimental plot units measuring $1 \mathrm{~m} \times 2 \mathrm{~m}$. This study aims to obtain the optimum dose of chicken manure on four varieties of mung bean plants and to find the varieties that have the best growth and yield of green bean plants in Ultisol. The results showed that the highest weight of 100 seeds was obtained from the Kutilang variety which was given chicken manure of 21.34 tons/ha with a maximum weight of 100 seeds of $8.82 \mathrm{~g}$. The highest yield of seed/plant weight was obtained from the application of chicken manure 19.61 tons/ha with a yield of $15.43 \mathrm{~g}$. Kutilang variety is the best variety compared to other varieties, with yields of seed weight/plant of $12 \mathrm{~g}$.
\end{abstract}

Keyword: mung bean, fertilizer, chicken manure, ultisol

\begin{abstract}
ABSTRAK
Ultisol umumnya mempunyai sifat fisika, kimia, dan biologi kurang menguntungkan. Pupuk kandang ayam diyakini mampu memperbaiki struktur tanah, meningkatkan kapasitas menahan air, meningkatkan $\mathrm{pH}$ tanah, meningkatkan kapasitas tukar kation, meningkatkan aktivitas biologi tanah, dan memudahkan penetrasi akar. Penelitian ini bertujuan untuk menentukan dosis optimum pupuk kandang ayam dalam meningkatkan pertumbuhan dan hasil empat varietas kacang hijau di Ultisol. Penelitian ini dilaksanakan menggunakan Rancangan Petak Terbagi (Split Plot). Dosis pupuk kandang ayam (0 ton/ha, 10 ton/ha, 20 ton/ha, dan 30 ton/ha) ditempatkan pada petak utama dan varietas kacang hijau (Vima-1, Vima-2, Kutilang, dan Murai) sebagai anak petak dengan satuan percobaan petakan berukuran $1 \mathrm{~m} \mathrm{x} 2 \mathrm{~m}$. Penelitian ini bertujuan untuk mendapatkan dosis pupuk kandang ayam optimum pada empat varietas tanaman kacang hijau, dan mendapatkan varietas yang memiliki pertumbuhan dan hasil tanaman kacang hijau terbaik di Ultisol. Hasil penelitian menunjukkan bobot 100 biji tertinggi diperoleh dari varietas Kutilang yang diberi pupuk kandang ayam sebesar 21,34 ton/ha dengan bobot 100 biji maksimum $8,82 \mathrm{~g}$. Hasil bobot biji/ tanaman tertinggi diperoleh dari pemberian pupuk kandang ayam 19,61 ton/ha dengan hasil 15,43 g. Varietas Kutilang merupakan varietas terbaik dibandingkan varietas lainnya, dengan hasil bobot biji/ tanaman sebesar $12 \mathrm{~g}$.
\end{abstract}

Kata kunci: kacang hijau, Ultisol, pupuk kandang ayam 


\section{PENDAHULUAN}

Kacang hijau (Vigna radiata L.) merupakan tanaman legum yang banyak dikonsumsi masyarakat Indonesia. Karena, memiliki kandungan gizi yang cukup, karbohidrat, protein yang tinggi, vitamin B1 dan B2 yang dibutuhkan oleh manusia. Rahman \& Agus (2011) menjelaskan bahwa kandungan protein dan karbohidrat merupakan kadungan gizi terbesar dari kacang hijau. Kacang hijau mengandung asam amino yang cukup tinggi, vitamin B1, dan B2 yang sangat dibutuhkan tubuh (Yusuf, 2014).

Produksi kacang hijau di Indonesia dari tahun ke tahun terus mengalami fluktuasi. Data Badan Pusat Statistik (2015) menunjukkan bahwa selama lima tahun terakhir produksi kacang hijau periode 2010-2015 berturut-turut: 291.705 ton, 341.342 ton, 284.257 ton, 204.670 ton, 244.589 ton, dan 271.463 ton. Kebutuhan kacang hijau nasional setiap tahunnya \pm 330.000 ton/ tahun sehingga Indonesia masih harus impor kacang hijau. Upaya yang dapat dilakukan untuk meningkatkan produksi diantaranya meningkatkan luas panen dan meningkatkan produktivitas. Meningkatkan luas panen melalui ekstensifikasi pada lahan subur sudah sulit dilakukan, sehingga memaksa memanfaatkan lahan sub optimal, antara lain Ultisol.

Ultisol memiliki potensi yang besar untuk dijadikan sebagai pilihan strategis pengembangan pertanian kedepannya untuk mengimbangi penyempitan lahan subur (Subowo, 2012). Ultisol memiliki sifat fisik warna tanah merah kuning, agregat tidak stabil, porositas tanah, dan kapasitas menahan air rendah (Andalusia et al., 2016). Sifat kimianya memiliki unsur hara rendah, $\mathrm{pH}$ rendah, dan keasaman tanah tinggi. Sifat biologinya, Ultisol terdapat sedikit mikro dan makro organisme, baik jenis dan kelimpahannya. Pemanfaatan tanah marginal perlu dilakukan pengelolaan kualitas dan kesehatan tanah, baik dari aspek fisik, kimia, dan biologi tanah. Salah satu usaha yang dapat dilakukan ialah dengan penambahan bahan organik.

Bahan organik merupakan bahan di dalam atau di permukaan tanah yang berasal dari sisa tumbuhan, hewan, dan manusia yang telah mengalami dekomposisi. Bahan organik yang berasal dari hewan sering disebut dengan kotoran ternak. Kotoran ternak umumnya dapat dijadikan sebagai pupuk organik. Saraswati et al. (2006) menjelaskan pupuk organik adalah nama kolektif untuk semua jenis bahan organik yang berasal dari tanaman dan hewan yang dapat dirombak menjadi hara tersedia bagi tanaman. Mayrowani (2016) menyatakan bahwa penggunaan pupuk organik mampu membentuk pertanian yang berwawasan lingkungan dan bebas residu sehingga memberikan keuntungan pada pembangunan pertanian. Salah satu contoh penggunaan pupuk organik yaitu pupuk kandang ayam.
Arifah (2015) mengemukakan pupuk kandang ayam memiliki kandungan unsur hara lebih tinggi dibanding pupuk kandang kambing dan sapi. Hal ini terlihat pada pertumbuhan vegetatif dan generatif yang lebih baik terhadap tanaman kentang. Sari et al. (2016) menambahkan bahwa pupuk kandang ayam potong memiliki kandungan $\mathrm{N}$ yang cukup tinggi sebesar 2,44\%, unsur P sebesar 0,67\%, dan unsur K sebesar $1,24 \%$ dengan perbandingan $\mathrm{C}$ - organik sebesar $16,1 \%$. Artinya setiap dosis pupuk kandang ayam 10 ton/ha maka hara $\mathrm{N}$ nya sebesar $244 \mathrm{~kg} / \mathrm{ha}$, P sebesar $67 \mathrm{~kg} / \mathrm{ha}$, dan $\mathrm{K}$ sebesar $124 \mathrm{~kg} / \mathrm{ha}$ dengan perbandingan C-organik $1610 \mathrm{~kg} / \mathrm{ha}$. Sutejo (2002) mengemukakan bahwa pupuk kandang ayam mengandung $\mathrm{N}$ tiga kali lebih besar dari pada pupuk kandang lainnya. Balitkabi (2017) merekomendasikan kebutuhan hara $\mathrm{N}, \mathrm{P}$, dan $\mathrm{K}$ pada tanaman kacang hijau di tanah kurang subur, N sebesar $98 \mathrm{~kg} / \mathrm{ha}, \mathrm{P} 101 \mathrm{~kg} / \mathrm{ha}$, dan K $140 \mathrm{~kg} / \mathrm{ha}$.

Penggunaan pupuk kandang ayam akan sangat efektif jika dosis yang diberikan sesuai dengan kebutuhan tanaman. Berdasarkan hasil penelitian Sabran et al. (2015) menyatakan bahwa pemberian dosis pupuk kandang 12 ton/ha memberikan pertumbuhan dan hasil kacang tanah yang tertinggi. Dosis pupuk kandang ayam sebanyak 10 ton/ha memberikan hasil tertinggi yaitu $2,73 \mathrm{~kg} /$ petak pada tanaman kacang tanah di Ultisol (Marlina et al., 2015).

Upaya lain untuk meningkatkan produksi kacang hijau dengan penggunaan benih lokal sudah sulit dilakukan. Karena, umurnya relatif lebih lama dan tidak tahan organisme pengganggu tanaman. Sehingga memaksa menggunakan varietas unggul benih kacang hijau. Berdasarkan hasil penelitian Holidi et al. (2016) menunjukkan bahwa varietas kacang hijau Vima-1, Vima-2, Kutilang, dan Murai masih mampu beradapatasi pada lingkungan yang tidak kondusif. Varietas kacang hijau Vima-1 merupakan varietas terbaik dibandingkan dengan varietas lainnya (Asaad et al., 2012). Hanjar (2016) juga menjelaskan bahwa varietas Vima-1 memberikan hasil terbaik dibandingkan dengan varietas Sriti, varietas Murai. Lestari \& Kuntyastuti (2016) mengemukakan bahwa varietas Kutilang di tanah Ultisol asal banten memiliki hasil paling tinggi terhadap pengamatan bobot 100 biji yaitu $8,01 \mathrm{~g}$.

Penggunaan varietas unggul merupakan teknologi produksi yang mudah, tepat digunakan, dan aman terhadap kelestarian lingkungan (Balitkabi, 2012). Beberapa varietas kacang hijau yang telah dirilis oleh Balitkabi antara lain Vima-1, Vima-2, Kutilang, dan Murai. Namun pengujian varietas tersebut pada Ultisol Bengkulu masih sedikit informasinya.

Penelitian ini bertujuan untuk mendapatkan dosis pupuk kandang ayam yang cocok pada varietas kacang hijau dan mendapatkan pertumbuhan dan hasil varietas kacang hijau yang terbaik di Ultisol. 


\section{METODE PENELITIAN}

Penelitian ini telah dilaksanakan pada bulan Oktober hingga Desember 2018 bertempat di Kelurahan Kandang Limun, Kecamatan Muara Bangkahulu, Kota Bengkulu pada ketinggian $15 \mathrm{~m}$ dpl.

Unit-unit percobaan ditempatkan sesuai Rancangan Petak Terbagi (Split Plot). Petak utama dosis pupuk kandang ayam yang terdiri atas empat taraf : 0 ton/ha, 10 ton/ha ( $2 \mathrm{~kg} /$ petak), 20 ton/ha (4 $\mathrm{kg} /$ petak), dan 30 ton $/ \mathrm{ha}$ (6 kg/petak). Sebagai anak petak yaitu varietas kacang hijau yang terdiri atas Vima-1, Vima-2, Kutilang, dan Murai. Data-data yang dikumpulkan meliputi data utama pertumbuhan dan hasil kacang hijau serta data pendukung berupa analisis tanah awal dan elemen agroklimat.

Data-data pertumbuhan dan hasil kacang hijau yang dikumpulkan dianalisis menggunakan analisis varian (ANAVA) taraf $5 \%$ dan 1\%. Apabila terdapat perbedaan respon pertumbuhan dan hasil yang nyata pada setiap pemberian dosis pupuk kandang ayam maka dilakukan metode Polinomial Ortogonal. Namun jika terdapat perbedaan yang nyata antar varietas kacang hijau dilakukan DMRT pada taraf 5\%.

\section{HASIL DAN PEMBAHASAN}

Rata-rata curah hujan saat penelitian pada bulan Oktober, November, dan Desember berturut-turut yaitu 10,16 mm, 19,5 mm, dan 19,80 mm (hari). Ratarata suhu udara berturut-turut yaitu $27,33{ }^{\circ} \mathrm{C}, 26,60$ ${ }^{\circ} \mathrm{C}$, dan $25,68{ }^{\circ} \mathrm{C}$. Rata-rata kelembaban udara 86,9 $\%, 89,76 \%$, dan $84,38 \%$.

Ultisol pada lahan percobaan memiliki $\mathrm{pH}$ tanah 4,12 yang tergolong sangat masam, N-total $0,37 \%$ (sedang), $\mathrm{P}$ total 7,7 ppm (sangat rendah), dan K-total 0,18308 me/100 katagori sangat rendah. Kondisi lahan tersinari cahaya matahari penuh, artinya tidak terdapat naungan baik itu disebabkan oleh tanaman lain ataupun pepohonan lainnya. Hasil analisis varian data partumbuhan dan hasil kacang hijau yang dikumpulkan disajikan pada Tabel 1.

Hasil analisis varians menunjukkan bahwa pemberian dosis pupuk kandang ayam memberi pengaruh yang sangat nyata terhadap tinggi tanaman, diameter batang, jumlah cabang produktif, jumlah polong/ tanaman, bobot biji/tanaman, dan bobot biji/petak. Perbedaan sangat nyata antar varietas terlihat pada tinggi tanaman, umur berbunga, bobot biji/polong, bobot biji/tanaman, dan bobot 100 biji. Sedangkan perbedaan yang sangat nyata pertumbuhan dan hasil varietas tanaman kacang hijau pada setiap dosis pupuk kandang ayam yang diberikan hanya terlihat pada bobot 100 biji.
Tabel 1. Analisis varian data pertumbuhan dan hasil tanaman kacang hijau

\begin{tabular}{|c|c|c|c|}
\hline \multirow{2}{*}{ Variabel tanaman } & \multicolumn{3}{|c|}{$\mathrm{F}$ hitung } \\
\hline & Dosis & Varietas & Interaksi \\
\hline Tinggi tanaman & $53,64^{* *}$ & $6,05^{* *}$ & $1,66^{\mathrm{ns}}$ \\
\hline Diameter batang & $15,47^{* *}$ & $0,39^{\mathrm{ns}}$ & $0,54^{\mathrm{ns}}$ \\
\hline Umur berbunga & $2,79^{\mathrm{ns}}$ & $28,64^{* *}$ & $0,69^{\mathrm{ns}}$ \\
\hline $\begin{array}{l}\text { Jumlah cabang } \\
\text { produktif }\end{array}$ & $36,09^{* *}$ & $2,17^{\mathrm{ns}}$ & $1,23^{\text {ns }}$ \\
\hline $\begin{array}{l}\text { Jumlah } \\
\text { polong/tanaman }\end{array}$ & $105,05^{* *}$ & $2,67^{\text {ns }}$ & $1,14^{\text {ns }}$ \\
\hline Bobot biji/polong & $4,65^{\mathrm{ns}}$ & $7,49^{* *}$ & $0,64^{\mathrm{ns}}$ \\
\hline Bobot biji/tanaman & $90,92^{* *}$ & $14,00^{* *}$ & $1,67^{\mathrm{ns}}$ \\
\hline Bobot $100 \mathrm{biji}$ & $3,97^{\mathrm{ns}}$ & $103,18^{* *}$ & $4,28^{* *}$ \\
\hline Bobot biji/petak & $229,56^{* *}$ & $0,43^{\text {ns }}$ & $1,27^{\mathrm{ns}}$ \\
\hline
\end{tabular}

Keterangan : ** : berpengaruh sangat nyata ; $\mathrm{ns}$ : berpengaruh tidak nyata

Dosis pupuk kandang ayam dan tinggi tanaman membentuk pola hubungan kuadratik $\mathrm{Y}=$ $12,41+4,248 x-0,105 x^{2}$ dengan nilai koefisien determinasi $\mathrm{R}^{2}=0,940$. Atas dasar pola hubungan ini diperoleh dosis optimum pupuk kandang ayam ratarata 20,22 ton/ha dan tinggi tanaman maksimum rata-rata 55,38 cm (Gambar 1).

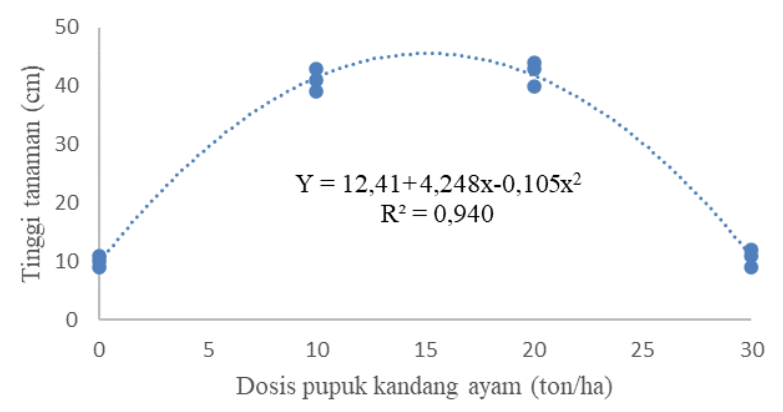

Gambar 1. Hubungan dosis pupuk kandang ayam dan tinggi tanaman

Dosis pupuk kandang ayam 20,22 ton/ha diyakini telah mampu menyediakan unsur hara yang dibutuhkan tanaman. Namun pada dosis pupuk kandang ayam yang melebihi takaran dosis optimum justru akan memperlambat pertumbuhan tinggi tanaman. 
Dosis pupuk kandang ayam 20,22 ton/ha memiliki kandungan hara $\mathrm{N}$ sebesar 492,88 kg/ha, $\mathrm{P}$ sebesar $135,47 \mathrm{~kg} / \mathrm{ha}$, dan $\mathrm{K}$ sebesar $250,72 \mathrm{~kg} / \mathrm{ha}$. Hal ini sesuai dengan hasil analisis pupuk kandang ayam oleh Sari et al. (2016) yang menunjukkan bahwa kandungan hara $\mathrm{N}$ cukup tinggi di dalam pupuk kandang ayam yaitu sebesar $2,44 \%$, unsur $\mathrm{P}$ sebesar $0,67 \%$, dan unsur K sebesar 1,24\%. Pupuk kandang ayam mengandung $\mathrm{N}$ tiga kali lebih besar dari pada pupuk kandang lainnya (Sutejo, 2002). Pupuk kandang ayam juga mampu memperbaiki sifat fisik dan biologi tanah (Marlina et al., 2015).

Varietas Kutilang menunjukkan tinggi tanaman tertinggi rata-rata $42,68 \mathrm{~cm}$ yang berbeda nyata dengan varietas Vima $1(35,26 \mathrm{~cm})$, namun berbeda tidak nyata dengan varietas Murai $(40,46 \mathrm{~cm})$ dan Vima-2 (38,59 $\mathrm{cm})$. Hasil penelitian Holidi et al. (2016) menunjukkan pertumbuhan tinggi tanaman pada varietas Kutilang, Murai, dan Vima-1 di tanah gambut masing-masing adalah $54,25 \mathrm{~cm}, 53,90 \mathrm{~cm}$ dan $46,10 \mathrm{~cm}$ sedangkan di tanah mineral $73,50 \mathrm{~cm}, 62,5 \mathrm{~cm}$ dan $54,75 \mathrm{~cm}$.

Dosis pupuk kandang ayam dan diameter batang membentuk pola hubungan kuadratik $\mathrm{Y}=2,637+$ $0,505 \mathrm{x}-0,012 \mathrm{x}^{2}$ dengan nilai koefisien determinasi $\mathrm{R}^{2}$ $=0,843($ Gambar 2). Atas dasar pola hubungan tersebut diperoleh dosis pupuk kandang ayam rata-rata 21,04 ton/ha yang menghasilkan diameter batang terbesar rata-rata $7,95 \mathrm{~mm}$.

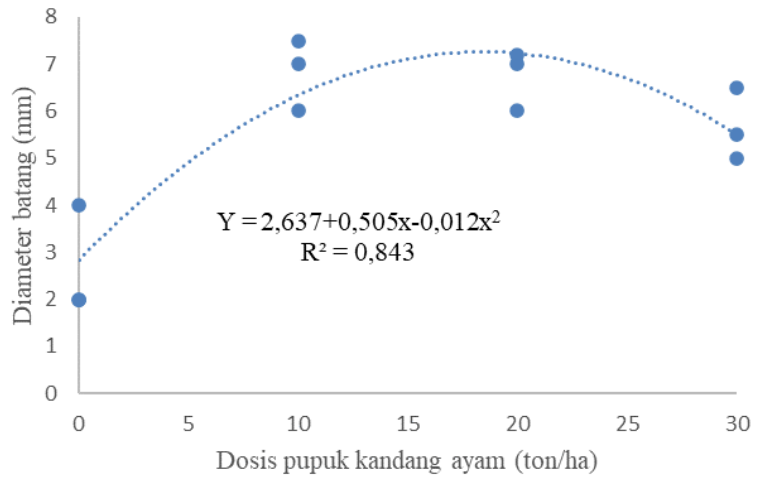

Gambar 2. Hubungan dosis pupuk kandang ayam dan diameter batang

Pemberian dosis pupuk kandang ayam dengan takaran dosis yang optimum mampu menyediakan unsur hara yang cukup bagi pertumbuhan diameter batang kacang hijau. Sabran et al, (2015) mengemukakan bahwa pertumbuhan vegetatif tanaman sangat dipengaruhi oleh jumlah unsur hara yang diserap oleh tanaman. Pertumbuhan batang terjadi karena adanya kandungan hara $\mathrm{N}, \mathrm{P}$, dan $\mathrm{K}$ di dalam bahan organik yang dapat meningkatkan diameter batang tanaman (Tamba et al., 2017).
Komponen hasil tanaman kacang hijau dengan dosis optimum pupuk kandang ayam, dapat dikatagorikan mampu menyetarakan dengan hasil deskripsi tanaman kacang hijau dari Balitkabi Malang. Pupuk kandang ayam juga mampu meningkatkan $\mathrm{pH}$ tanah sehingga sesuai untuk pertumbuhan dan hasil tanaman. Analisis tanah awal menunjukkan $\mathrm{pH}$ tanah 4,12 yang dikatagorikan sangat masam dan belum memenuhi syarat tumbuh tanaman kacang hijau. Purwono \& Purnamawati (2007) menjelaskan bahwa kemasaman tanah yang dipelukan untuk pertumbuhan dan hasil tanaman kacang hijau secara maksimum antara $\mathrm{pH}$ $5,5-6,5$.

Demikian pula dosis pupuk kandang ayam dan jumlah cabang produktif juga membentuk pola hubungan kuadratik $\mathrm{Y}=1,257+0,457 \mathrm{x}-0,010 \mathrm{x}^{2}$ dan nilai $\mathrm{R}^{2}=$ 0,839 (Gambar 3).

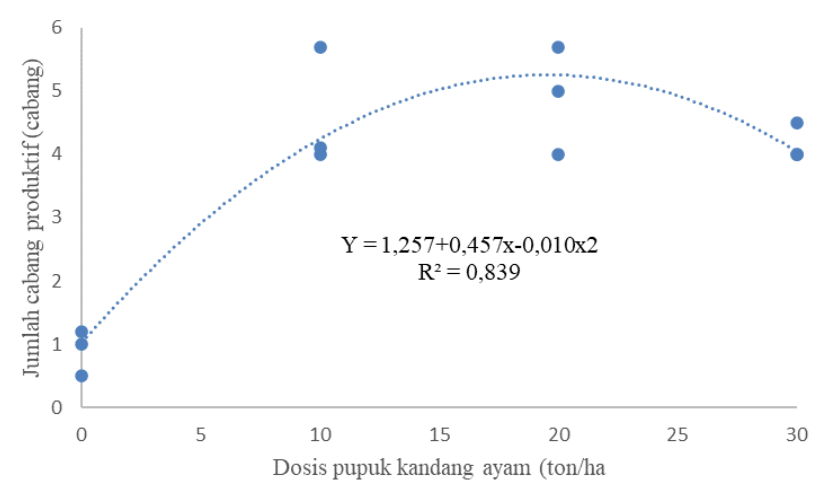

Gambar 3. Hubungan dosis pupuk kandang ayam dan jumlah cabang produktif

Atas dasar hubungan tersebut diperoleh dosis optimum pupuk kandang ayam sebesar 22,85 ton/ha yang menghasilkan jumlah cabang produktif terbanyak rata-rata 6,47 cabang. Hasil penelitan Latuamury (2015) menunjukkan bahwa pupuk kandang ayam nyata pengaruhnya terhadap jumlah cabang produktif tanaman kacang hijau. Jumlah cabang terbanyak dibandingkan dengan pupuk organik lainnya yaitu 3,72 cabang.

Pembentukan jumlah cabang produktif tanaman kacang hijau membutuhkan unsur hara esensial di antaranya adalah unsur hara N. Di dalam pupuk kandang ayam terkandung unsur hara $\mathrm{N}$ lebih tinggi dibandingkan unsur hara lainnya (Sari et al., 2016). Cabang tanaman dapat terbentuk melalui proses pembelahan dan pembesaran sel tanaman dengan bantuan unsur hara dan mineral. Dalam hal ini unsur hara $\mathrm{N}$ sangat berperan dalam proses pembelahan dan pembesaran sel (Faluvi et al., 2011).

Dosis pupuk kandang ayam dan jumlah polong/tanaman membentuk pola hubungan kuadratik dengan persamaan regresi $Y=1,927+1,856 x-0,047 x^{2}$, dan nilai $\mathrm{R}^{2}=0,961$ (Gambar 4). 


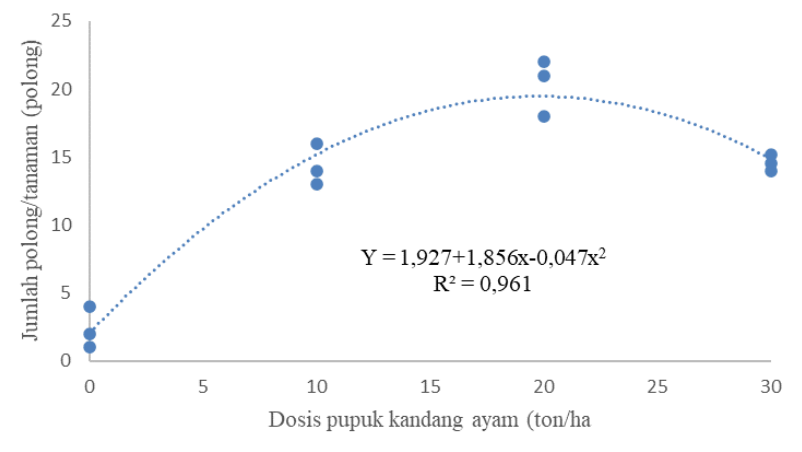

Gambar 4. Hubungan dosis pupuk kandang ayam dan jumlah polong/tanaman

Atas dasar persamaan di atas maka diperoleh dosis pupuk kandang ayam optimum 19,74 ton/ha yang menghasilkan jumlah polong/tanaman terbanyak rata-rata 20,25 polong. Jumlah polong/tanaman erat hubungannya dengan jumlah cabang produktif tanaman. Semakin banyak cabang tanaman, maka peluang terbentuknya polong juga semakin banyak. Cabang produktif yang semakin banyak maka semakin banyak pula polong/tanaman yang terbentuk (Riyaningsih et al., 2018).

Hubungan antara dosis pupuk kandang ayam dan bobot biji/tanaman membentuk pola hubungan kuadratik dengan persamaan regresi $\mathrm{Y}=1,589+$ $1,412 x-0,036 x^{2}$, nilai $R^{2}=0,972$ (Gambar 5).

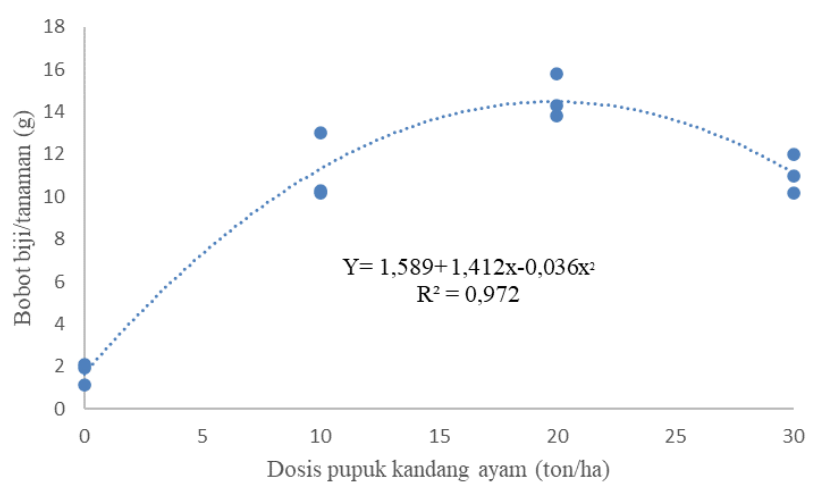

Gambar 5. Hubungan dosis pupuk kandang ayam dan bobot biji/tanaman

Atas dasar persamaan regresi yang diperoleh dapat diketahui bahwa dosis optimum pupuk kandang ayam sebesar 19,61 ton/ha dengan hasil maksimum bobot biji/tanaman 15,43 g. Dosis optimum merupakan takaran dosis yang tepat diaplikasikan pada tanaman, apabila pupuk kandang ayam yang diberikan melebihi takaran dosis optimum maka berdampak buruk terhadap hasil tanaman kacang hijau. Luthfyrakhman \& Susila (2013) menjelaskan bahwa pemberian dosis pupuk kandang ayam yang melebihi dosis optimum dapat menurunkan hasil panen tomat.

Bobot biji/tanaman sangat dipengaruhi oleh pertumbuhan vegetatif. Jika pertumbuhan vegetatifnya baik maka pertumbuhan generatifnya juga akan baik. Namun belum bisa dipastikan demikian, karena bisa dipengaruhi oleh faktor genetik dan lingkungan. Novrika et al. (2016) menyatakan bahwa terjadi hubungan antara dua sifat atau yang dikenal dengan korelasi. Dua sifat dikatakan berkorelasi apabila perubahan pada sifat yang satu akan diikuti dengan perubahan pada sifat yang lain secara teratur dengan arah yang sama ataupun berlawanan.

Hubungan antara dosis pupuk kandang ayam dan bobot biji/petak membentuk pola hubungan kuadratik dengan persamaan regresi $\mathrm{Y}=-13,13+35,72 \mathrm{x}-$ $0,943 x^{2}$, nilai $R^{2}=0,867$ (Gambar 6).

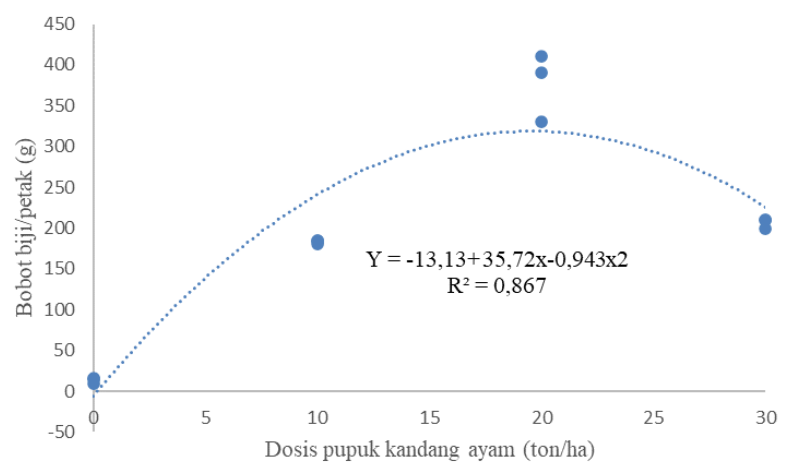

Gambar 6. Hubungan dosis pupuk kandang ayam dan bobot biji/petak

Atas dasar persamaan regresi di atas diperoleh dosis optimum pupuk kandang ayam sebesar 18,93 ton/ha dengan hasil maksimum bobot biji/petak rata-rata 325,13 g. Hasil yang diperoleh ini jika dikonversikan maka hasil panen tanaman kacang hijau ini mencapai $1625,13 \mathrm{~kg} / \mathrm{ha}$ atau setara dengan 1,62 ton/ha. Secara umum bahwa hasil panen tanaman kacang hijau ini telah memenuhi standar hasil Balitkabi. Semakin banyak jumlah polong, bobot biji/polong, dan bobot biji/tanaman, maka kompenen hasil biji/petak akan mengikuti variabel hasil sebelumnya. Hubungan antar komponen hasil yang diamati merupakan suatu analisis yang dapat digunakan untuk menentukan derajat keeratan hubungan (Hidayat, 2009)

Umur berbunga tanaman kacang hijau varietas Vima 1 dan varietas Vima 2 berbeda tidak nyata, sama halnya dengan Varietas Kutilang dan Murai yang juga berbeda tidak nyata. Namun varietas Vima 1 dan Vima 2, umur berbunganya berbeda nyata dengan varietas Kutilang dan Murai (Tabel 2). Hasil penelitian Balitkabi (2012) mendeskripsikan varietas kacang hijau Vima 1 umur berbunga 33 hari setelah tanam, 
varietas Vima 2 umur berbunga 33 hari setelah tanam, varietas Kutilang umur berbunga 35-38 hari setelah tanam, dan varietas Murai umur berbunga 35 hari setelah tanam. Namun hasil penelitian Holidi et al, (2016) pada tanah mineral menunjukkan bahwa varietas Vima 1 umur berbunga 37,5 hari, varietas Kulitang 37,5 hari, dan Murai umur berbunga 37,2 hari. Sedangkan, di tanah gambut Vima 1 umur berbunga 41,5 hari, Kutilang umur berbunga 40,1 hari, dan Murai 40,3 hari.

Bobot biji/polong tanaman kacang hijau memiliki bobot yang berbeda tidak nyata pada varietas Vima 1 dan Murai. Varietas Vima 2 memiliki bobot biji/polong berbeda tidak nyata dengan varietas $\mathrm{Ku}-$ tilang dan Murai, namun berbeda nyata dengan varietas Vima 1 (Tabel 2). Bobot biji /polong sangat dipengaruhi oleh jumlah cabang yang terbentuk, semakin banyak cabang yang terbentuk maka semakin banyak pula jumlah polong yang dihasilkan (Hapsari et al., 2017).

Tabel 2. Rata-rata umur berbunga, bobot biji/polong dan bobot biji/tanaman pada empat varietas kacang hijau

\begin{tabular}{lccc}
\hline Varietas & $\begin{array}{c}\text { Umur } \\
\text { berbunga } \\
\text { (hari) }\end{array}$ & $\begin{array}{c}\text { Bobot } \\
\text { biji/ } \\
\text { polong } \\
(\mathrm{g})\end{array}$ & $\begin{array}{c}\text { Bobot biji/ } \\
\text { tanaman } \\
(\mathrm{g})\end{array}$ \\
\hline Vima 1 & $34,50 \mathrm{~b}$ & $0,62 \mathrm{c}$ & $9,12 \mathrm{c}$ \\
Vima 2 & $34,70 \mathrm{~b}$ & $0,74 \mathrm{ab}$ & $10,17 \mathrm{~b}$ \\
Kutilang & $37,50 \mathrm{a}$ & $0,82 \mathrm{a}$ & $12,00 \mathrm{a}$ \\
Murai & $37,00 \mathrm{a}$ & $0,67 \mathrm{bc}$ & $9,81 \mathrm{bc}$ \\
\hline
\end{tabular}

Keterangan: Angka-angka yang diikuti oleh huruf yang sama pada kolom yang sama, berbeda tidak nyata pada DMRT 5\%

Bobot biji/tanaman tanaman kacang hijau menunjukkan bahwa varietas Kutilang berbeda nyata dengan tiga varietas lainnya. Varietas Vima 2 berbeda tidak nyata dengan varietas Murai, namun berbeda nyata dengan varietas Vima 1 dan Kutilang. Varietas Kutilang memiliki bobot biji tertinggi dibandingkan tiga varietas lainnya yaitu dengan ratarata $12 \mathrm{~g}$ /tanaman. Berdasarkan hasil penelitian Hakim \& Suryamto (2012) varietas Kutilang memiliki bobot biji/tanaman sebesar 10,5 g, varietas Vima memiliki bobot biji/tanaman hanya sebesar $9 \mathrm{~g}$, dan varietas Murai sebesar 9,5 g.

Pemberian dosis pupuk kandang ayam hingga 20 ton/ha dapat meningkatkan bobot 100 biji pada masing-masing varietas, namun peningkatan dosis pupuk kandang ayam hingga 30 ton/ha dapat menurunkan bobot 100 biji (Gambar 7).

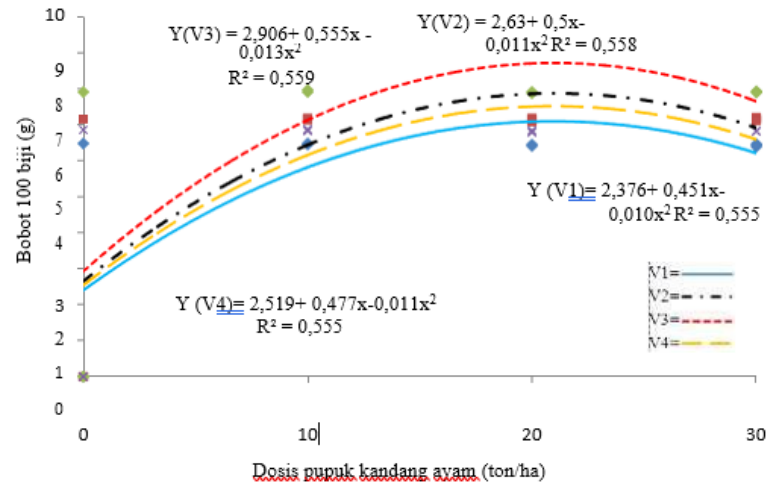

Gambar 7. Hubungan dosis pupuk kandang ayam dan bobot 100 biji pada empat varietas kacang hijau

Berdasarkan persamaan regresi, varietas Kutilang memberikan hasil tertinggi bobot 100 biji dibandingkan tiga varietas lainnya. Varietas Kutilang dengan pemberian dosis pupuk kandang ayam optimum 21,34 ton/ha menghasilkan bobot 100 biji 8,82 g. Varietas Vima 2, Murai, dan Vima 1 dengan pemberian dosis optimum masing-masing 22,72 ton/ ha, 21,68 ton/ha, 22,55 ton/ha menghasilkan bobot 100 biji maksimum berturut-turut $8,32 \mathrm{~g}, 7,69 \mathrm{~g}$, dan 7,46 g.

Hasil penelitian Hakim \& Suryamto (2012), bobot 100 biji varietas kacang hijau yang diuji berkisar antara 5,3 - 7,8 g. Varietas Kutilang menghasilkan bobot 100 biji tertinggi dibandingkan dengan varietas lainnya, yaitu 7,8 g. Bobot 100 biji varietas Kutilang memberi pengaruh yang nyata dibandingkan dengan varietas Vima. Hal ini disebabkan varietas Kutilang memiliki ukuran biji yang besar. Trustinah et al. (2017) menyatakan bahwa varietas Vima 1 memiliki ukuran biji yang kecil, sehingga bobot 100 biji yang diperoleh juga rendah. Varietas Vima 1 menghasilkan bobot 100 biji 5,13 g dan varietas $\mathrm{Ku}-$ tilang menghasilkan bobot 100 biji sebesar 7,5 g (Asaad et al., 2012).

\section{KESIMPULAN}

Hasil bobot 100 biji tertinggi diperoleh dari varietas Kutilang yang diberi pupuk kandang ayam sebesar 21,34 ton/ha dengan bobot 100 biji maksimum 8,82 g. Hasil bobot biji/tanaman tertinggi diperoleh dari pemberian pupuk kandang ayam 19,61 ton/ha dengan hasil 15,43 g. Varietas Kutilang merupakan varietas terbaik dibandingkan varietas lainnya, dengan hasil bobot biji/tanaman sebesar $12 \mathrm{~g}$. 


\section{DAFTAR PUSTAKA}

Andalusia, B., Zainabun Z. \& Arabia, T. (2016). Karakteristik tanah ordo ultisol di Perkebunan Kelapa Sawit PT. Perkebunan Nusantara I (Persero) Cot Girek kabupaten Aceh Utara. Jurnal Kawista Agroteknologi, 1(1), 45-49.

Arifah, S.M. (2015). Aplikasi macam dan dosis pupuk kandang pada tanaman kentang. Jurnal Gamma, $8(2), 80-85$.

Asaad, M., Ahmad A. \& Moko, H.D. ( 2012). Uji Daya Hasil Beberapa Varietas Kacang Hijau di Bone Bolango. Prosiding Seminar Hasil Penelitian Tanaman Aneka Kacang dan Umbi, Gorontalo: 15-16 April. Pp. 473-476.

Badan Pusat Statistik (2015). Produksi kacang hijau menurut provinsi. http://www.bps.go.id. 26 April 2018.

Balitkabi (2012). Deskripsi Varietas Unggul Kacangkacangan dan Umbi-umbian. Balai Penelitan Tanaman Aneka Kacang dan Umbi, Malang.

Balitkabi (2017). Budidaya Kacang Hijau di Lahan Kering. Balai Penelitan Tanaman Aneka Kacang dan Umbi, Malang.

Faluvi, P.K., Yetti, H. \& Anom, E. (2011). Peningkatan Produksi Kacang Hijau (Vigna radiata L.) dengan Pemberian Pupuk Kandang Ayam dan NPK. Skripsi. Jurusan Budidaya Pertanian, Fakultas Pertanian, Universitas Riau, Pekanbaru.

Hakim, L. \& Suryamto (2012). Korelasi antar-karakter dan sidik lintas antara komponen hasil dengan hasil biji kacang hijau (Vigna radiata L.). Berita Biologi,11(3), 339-349.

Hanjar, P.A. (2016). Respon Pertumbuhan dan Hasil Tiga Varietas Kacang Hijau terhadap Dosis Pupuk NPK. UPN" Veteran" Yogyakarta.

Hapsari, R., Indradewa, D. \& Ambarwat, E. (2017). Pengaruh pengurangan jumlah cabang dan jumlah buah terhadap pertumbuhan dan hasil tomat (Solanum lycopersicum L.). Vegetalika, 6(3), 37-49.

Hidayat, R. (2009). Hubungan antara komponen pertumbuhan dan komponen hasil dengan hasil cabai persilangan talang Semut/TIT super di Kepahiang dan Curup. Skripsi. Fakultas Pertanian Universitas Bengkulu, Bengkulu.

Holidi, H., Bahri S. \& Karno (2016). Pertumbuhan dan produksi tiga varietas kacang hijau (Vigna radiata L.) di tanah gambut dan mineral. Prosiding Seminar Nasional Lahan Suboptimal, Palembang: 20-21 Oktober 2016. pp. 384-591.

Latuamury, N. (2015). Pengaruh tiga jenis pupuk kandang terhadap pertumbuhan dan produksi tanaman kacang hijau (Vigna radiata L.), Jurnal Agroforestri, 10(2), 210-216.
Lestari, S.A.D. \& Kuntyastuti, H. (2016). Pengaruh pupuk kandang dan pupuk anorganik terhadap berbagai varietas kacang hijau di tanah masam. Buletin Palawija, 14(2), 55-62. DOI: https://10.21082/bul palawija.v14n2.2016.p55 -62 .

Luthfyrakhman, H. \& Susila, A.D. (2013). Optimasi dosis pupuk anorganik dan pupuk kandang ayam pada budidaya tomat hibrida (Lycopersicon esculentum Mill. L.) Buletin Agrohorti, 1(1), 119-126.

Marlina, N., R. Aminah R. \& Setel L.R. ( 2015). Aplikasi pupuk kandang kotoran ayam pada tanaman kacang tanah (Arachis hypogeae L.). Biosaintifika Journal Of Biology \& Biology Education, 7(2), 137-141.

Mayrowani, H. (2016). Pengembangan pertanian organik di Indonesia. In forum Penelitian Agro Ekonomi, 30 (2), 91-108.

Novrika D., Herison, C., \& Fahrurrozi (2016). Korelasi antar komponen pertumbuhan vegetatif dan generatif dengan hasil pada delapan belas genotipe gandum di dataran tinggi. Akta Agrosia, 19(2), 93-103. DOI: https://doi.org/ 10.31186/aa.19.2.93-103.

Purwono \& Purnamawati H. (2007). Budidaya 8 Jenis Tanaman Pangan Unggul. Penebar Swadaya, Jakarta.

Rahman, T. \& Agus T. (2011). Pemanfaatan kacang hijau (phaseolus radiatus L.) menjadi susu kental manis kacang hijau. Prosiding Seminar Nasional Penelitian dan PKM Sains, Teknologi, dan Kesehatan, Bandung, 22 Juni 2011. pp. 223-230.

Riyaningsih, A.D., Supriyon \& Jauhari, S. (2018). Pertumbuhan dan hasil kacang hijau dari berbagai populasi dengan mulsa organik. Agrotechnology Research Journal, 2(2), 58-62.

Rahmat ( 1997). Kacang Hijau, Budi Daya dan Pasca Panen. Kanisius. Jakarta.

Sabran, I., Soge, Y.P.D. \& Wahyudi, I. (2015). Pengaruh pupuk kandang ayam bervariasi dosis terhadap pertumbuhan dan hasil tanaman kacang tanah (Arachis hypogeae L.) pada Entisol Sidera. Agrotekbis, 3(3), 297-302.

Saraswati, R., Simanungkalit, R.D.M., Suriadikarta, Setyorini, D. \& Hartatik, W. (2006). Pupuk Organik dan Pupuk Hayati. Balai Besar Penelitian dan Pengembangan Sumberdaya Lahan Pertanian, Bogor.

Sari, M., Pasigai, A.,Wahyudi, I. \& Kurnia. (2016). Pengaruh pupuk kandang ayam terhadap pertumbuhan dan hasil tanaman kubis bunga (Brassica oleracea var. bathytis) pada Oxic Dystrudepts Lembantongoa. Agrotekbis, 4(2), 152-159. 
Subowo, G. (2012). Pemberdayaan sumberdaya hayati tanah untuk rehabilitasi tanah ultisol terdegradasi. Jurnal Sumberdaya Lahan, 6(2), 79-88.

Sutejo, M.M. (2002). Pupuk dan Cara Pemupukan. Rineka Cipta, Jakarta.

Tamba, H., Irmansyah, T. \& Hasanah, Y. (2017). Respons pertumbuhan dan produksi kedelai (Glycine max L.) Merill) terhadap aplikasi pupuk kandang sapi dan pupuk organik cair. Jurnal Agroekoteknologi FP US, 5(2), 307-314.
Trustina, Iswanto, R. \& Hapsari, R.T. (2017). Seleksi galur kacang hijau berbiji kecil. Buletin Palawija, 15(1), 24-31.

Yusuf (2014). Pemanfaatan kacang hijau sebagai pangan fungsional mendukung diversifikasi pangan di nusa tenggara timur. Prosiding Seminar Hasil Penelitian Tanaman Aneka Kacang dan Umbi. Nusa Tenggara Timur: 3 April 2014. pp.741- 746. 